\author{
Grażyna MICHALCZUK ${ }^{1}$ \\ Urszula KONARZEWSKA ${ }^{2}$
}

\title{
STANDARDIZATION OF CORPORATE SOCIAL RESPONSIBILITY REPORTING
}

\begin{abstract}
The aim of the article is to present standards, norms and guidelines being developed for standardization of social reporting aimed at communication on economic, social and environmental impact of market activities undertaken by companies. The article also focuses on the empirical research showing their practical implementation in the process of reporting concerning corporate social responsibility by companies included in the RESPECT Index. Considering the formulated purpose, the article assumes the following research hypothesis: the companies included in the RESPECT Index perceive the need to ensure the reliability and comparability of disclosed non-financial data, through the use of most common standards, norms and guidelines concerning the area of corporate social responsibility reporting. The realization of the article's purpose as well as the verification of the adopted research hypothesis is based on the review of the literature and documents containing recommendation concerning the reporting of corporate social responsibility as well as an analysis of the content of non-financial reports prepared by companies covered by the survey. Results of the research lead to the conclusion that regulations for corporate social responsibility reporting occupy a significant place in reports prepared by companies included in the RESPECT Index. Sustainability reporting guidelines and standards prepared by the Global Reporting Initiative are of particular importance in this field. However, it is necessary to take further steps to improve the quality of published reports and increase the level of their external verification, which give confidence that reporting data are reliable and can be basis for decision-making by stakeholders.
\end{abstract}

Keywords: corporate social responsibility reporting, standardization, RESPECT Index Companies.

\footnotetext{
${ }^{1}$ Grażyna Michalczuk,DSc, PhD, Associate Professor, University of Bialystok, Faculty of Economics and Management, Department of Finance, Accounting and Computer Science, ul. Warszawska 63, 15-062 Białystok, Poland, e-mail: g.michalczuk@uwb.edu.pl (corresponding author), ORCID: 0000-0003-0546-4456.

Dr hab. Grażyna Michalczuk, prof. UwB, Uniwersytet w Białymstoku, Wydział Ekonomii i Zarządzania, Katedra Finansów, Rachunkowości i Informatyki, ul. Warszawska 63, 15-062 Białystok, e-mail: g.michalczuk@uwb.edu.pl (autor korespondencyjny), ORCID: 0000-0003-0546-4456.

${ }^{2}$ Urszula Konarzewska, MSc, University of Bialystok, Faculty of Economics and Management, Department of Finance, Accounting and Computer Science, ul. Warszawska 63, 15-062 Białystok, Poland, e-mail: u.konarzewska@uwb.edu.pl, ORCID: 0000-0003-1257-3749.

Mgr Urszula Konarzewska, Uniwersytet w Białymstoku, Wydział Ekonomii i Zarządzania, Katedra Finansów, Rachunkowości i Informatyki, ul. Warszawska 63, 15-062 Białystok, e-mail: u.konarzewska@uwb.edu.pl, ORCID: 0000-0003-1257-3749.
} 


\section{INTRODUCTION}

The rising importance of corporate social responsibility in the practice of enterprises determines their need for directing activities not only at achieving high project profitability but also a necessity to include within their strategies the expectations of other market participants. These expectations are connected both with initiating particular activities within the closer as well as the more distant environment but also with communicating related information. Discretion as well as the varying scope of information presented by individual entities remains problematic ${ }^{3}$. That is the reason that initiation of activities meant to standardize delivered data in the area of corporate social responsibility is important.

The aim of the article is to present standards, norms and guidelines regulating matters of non-financial reporting as well as to present empirical research showing their practical implementation in the process of reporting concerning corporate social responsibility by companies included in the RESPECT Index.

Considering the formulated purpose, the article assumes the following research hypothesis: the companies included in the RESPECT Index perceive the need to ensure the reliability and comparability of disclosed non-financial data, through the use of most common standards, norms and guidelines concerning the area of corporate social responsibility reporting.

The realization of the article's purpose as well as the verification of the adopted research hypothesis is based on the review of literature and documents containing recommendations concerning the reporting of corporate social responsibility as well as an analysis of the content of non-financial reports prepared by companies belonging to the RESPECT Index.

The focus only on companies included in the RESPECT index means that conducted analysis does not fully exhaust the issues related to application of standards, norms and guidelines in the process of corporate social responsibility reporting by companies functioning on the Polish market. However, it provides a detailed information about the practices undertaken in this area by companies with the highest standards of social responsibility, whose activity very often becomes a model conduct for other economic actors.

\section{SELECTED INITIATIVES FOR THE STANDARDIZATION OF REPORTS DEALING WITH CORPORATE SOCIAL RESPONSIBILITY}

Regardless of the form of reporting used by individual entities to publish information related to corporate social responsibility the range of the subject matter within the data presented as well as its transparency and comparability is becoming more and more significant. For that reason, there are initiatives which aim to establish standards for such

\footnotetext{
${ }^{3}$ This is reflected in research described in the Investment and Enterprise Responsibility Review: Analysis of investor and enterprise policies on corporate social responsibility. It draws attention to the fact that CSR is a significant area of enterprises' self-regulation and most of the largest international corporations publish CSR reports. They differ from one another which creates problems with this information being used by stakeholders for decision-making (Investment and Enterprise Responsibility Review: Analysis of investor and enterprise policies on corporate social responsibility, United Nations Conference on Trade and Development, New York and Geneva, 2011, p. 3).
} 
reporting. To attain this goal there is an attempt to develop standards, norms and guidelines (figure 1).

They are, on the one hand meant to facilitate the process of reporting non-financial information and, on the other hand, enable the users of such reports to gain useful and reliable information ${ }^{4}$.

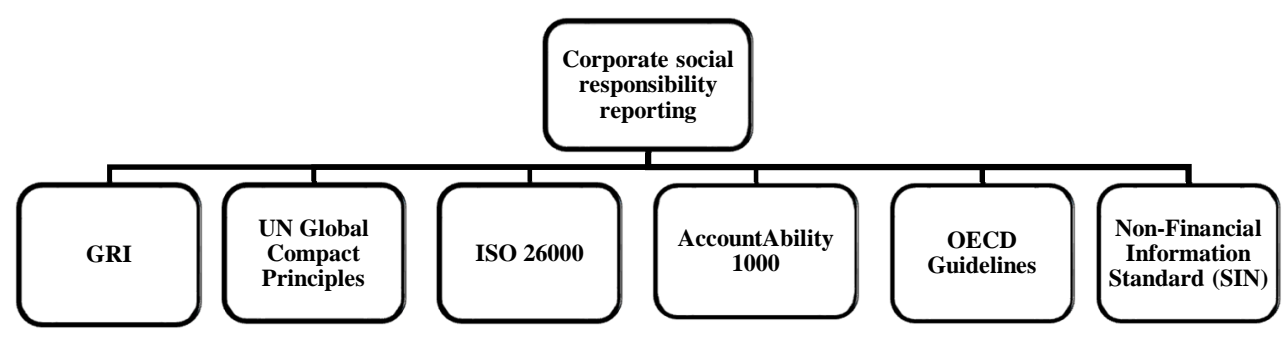

Figure 1. Standards, guidelines and norms for corporate social responsibility reporting

Source: Author's own work based on: J. Samelak, Zintegrowane sprawozdanie przedsiębiorstwa spotecznie odpowiedzialnego, Poznań 2013, p. 174; J. Kacprzak, L. Anam., Raportowanie niefinansowe. Poradnik dla raportujacych firm, Warszawa 2017, p. 12-17.

One of the most prevalent sets of regulations concerning corporate social responsibility is the one developed by Global Reporting Initiative (GRI) ${ }^{5}$. These are continually being improved through establishing dialogue with various groups of stakeholders, representatives of the scientific environment as well as business specialists and practitioners from different countries. Being the result of a consensus between all parties involved they are a reflection of the most current and desired solutions within this area ${ }^{6}$. The GRI G4 guidelines published in May of 2013 are still in force today but in July of 2018 GRI Sustainability Reporting Standards (GRI Standards) will become effective. The main aim of introducing GRI Standards is to increase their availability to reporting organization through the use of less complicated language as well as the utilization of more flexible structures and clearer requirements ${ }^{7}$.

GRI is characterized by a high level of flexibility which means that it can be used by any organization regardless of its legal status, business profile, size or location. Although these regulations do not compel entities to use a predetermined form of reporting they do,

${ }^{4}$ E. Różańska, Integracja standardów raportowania społecznej odpowiedzialności przedsiębiorstw, „Studia Oeconomica Posnaniensia” 2015, Vol. 3, No. 1, p. 168.

5 Is an independent non-profit organization oriented at supporting the development of sustainable world economy in which individual entities manage their own responsibility for the economic, social and environmental effects of their activity as well as communicate related data in a transparent manner (M. Mazurowska, Analiza porównawcza wytycznych Global Reporting Initative oraz International Integrated Reporting Comitee, „Studia Oeconomica Posnaniensia” 2015, Vol. 3, No. 1, p. 138).

${ }^{6}$ S. Pakowska, Wytyczne G3 I G3.1 Global Reporting Initiative dotyczace raportowania kwestii zrównoważonego rozwoju - analiza porównawcza, ,Zarządzanie i Finanse” 2012, nr 1 (2), p. 548.

${ }^{7}$ G4 Guidelines Transition to Standards, https://www.globalreporting.org/information/g4/transitionto-standards/Pages/default.aspx (access: 11.02.2018). 
however, stipulate precisely what should be reported and the manner in which it should be done. They define rules of reporting which contain descriptions of results to be accomplished and toward which the enterprise should strive in the process of reporting the economic, social and environmental effects of their operation. The preparation of reports on the basis of these rules makes it easier for entities to show the impact of their completed projects on individual groups of stakeholders and, as a result, to select and disclose the most significant matters related to them ${ }^{8}$.

They also show the scope of required disclosures ${ }^{9}$ :

1) General Standard Disclosures which relate to the description of the operating conditions of a given entity enabling the understanding of the functioning character of the company as well as its approach toward the issue of sustainable development and reporting related data;

2) Specific Standard Disclosures which concern the description of a given entity's approach to management - the manner in which it identifies economic, social and environmental effects of its operations, analyzes them and attempts to react to them.

An important characteristic of regulations prepared by the Global Reporting Initiative is the fact that they can be used in combination with other initiatives related to corporate social responsibility. One of such initiatives is the UN Global Compact (UN GC) establishing a global network of organizations declaring cooperation and development in the area of the ten principles referring to the four priority areas of corporate social responsibility: human rights, labor, environmental and anti-corruption standards ${ }^{10}$.

Entities belonging to the Global Compact are obliged to maintain informational transparency through the publication of an annual report (Communication on Progress Report), which, other than its reporting role, also functions as an important criterion for status assessment of a given entity and the level of its engagement in the realization of CSR principles $^{11}$. In accordance with the guidelines the scope of information within this type of a document should also encompass the general manager's statement regarding the continued support for the initiative as well as information concerning practical activities realized by the company in relation to the ten selected principles. Additionally, it should also, in a measurable way and through the use of standard reporting indicators including those specified by GRI guidelines, present data regarding the impact of in-progress undertakings on the close and broader environment of the entity ${ }^{12}$.

It must be stressed that both initiatives are mutually compatible since they are a part of a uniform set of values for entities who want to implement the concept of social responsi-

${ }^{8}$ L. Anam, Zasady raportowania - podstawa prawidtowego sporzadzania raportów [in:] N. Ćwik (ed.), Wspólna odpowiedzialność. Rola raportowania społecznego, Warszawa, 2013, p. 74.

9 A. Paszkiewicz, A. Szadziewska, Raportowanie rozwoju zrównoważonego przedsiębiorstw wedtug wytycznych GRI, Zeszyty Naukowe Uniwersytetu Szczecińskiego nr 668 „Finanse, Rynki Finansowe, Ubezpieczenia", 2011, nr 41, p. 634.

${ }^{10}$ E. Lemus, The importance of CSR in Financial Reporting Standards, „Global Journal of Management and Business Research: D Accounting and Auditing”, 2016, Vol. 16, Issue 2, p. 25.

${ }^{11}$ R. Dyląg, E. Puchalska, Raportowanie zagadnień środowiskowych $i$ spotecznych, „Zeszyty Teoretyczne Rachunkowości”, t. 75 (131), Warszawa 2014, p. 28.

${ }^{12}$ United Nations Global Compact, After the signature. A Guide to engagement in the United Nations Global Compact, 2012, https://www.unglobalcompact.org/docs/news_events/8.1/after_the_signature.pdf, p. 20 (access: 10.02.2018). 
bility and the practice of reporting related data. As a result many entities preparing reports dealing with social responsibility do not have to choose between them but can simultaneously use the Global Compact principles as well as the Global Reporting Initiative guidelines ${ }^{13}$.

The ISO 26000 norm containing a wide spectrum of issues concerning the concept of CSR is yet another set of regulations which is fully compatible with the GRI guidelines. It identifies areas which entities should consider during the realization of their undertakings and which concern such issues as: organizational governance, human rights, labor practices, the environment, fair operating practices, consumer issues as well as community involvement and development ${ }^{14}$. Unlike most other standards of this type the ISO 26000 norm is not subject to certification ${ }^{15}$. It is only a practical guidebook referring to the application of rules for corporate social responsibility in everyday business practice.

Standards from the AccountAbility1000 (AA1000) series which analyze the scope of disclosures within reports through the prism of their users keeping in mind issues concerning stakeholders' involvement and their cooperation with the company is another initiative upon which the process of reporting corporate social responsibility may also be based ${ }^{16}$. The AA1000 series of standards consists of three standards all of which support the entity at different levels of its relationship building with the stakeholders. These include ${ }^{17}$ : the AA1000APS standard (AA1000 Account Ability Principles Standard), the AA1000SES standard (AA1000 Stakeholder Engagement Standard) as well as the AA1000AS standard (AA1000 Assurance Standard).

The most universal collection of guidelines relating to corporate social responsibility as well as to reporting data related to it has been developed by the Organization for Economic Cooperation and Development (OECD). It contains a set of voluntarily used rules and behavior norms and relate to such issues as: human rights, free access to information, employment and industrial relations, environmental protection, corruption prevention or the protection of consumer rights ${ }^{18}$.

Within the social reporting standardization process activities undertaken by the International Integrated Reporting Council (IIRC) are also significant. They aim to develop a reporting standard which would allow the presentation of a manner in which the organization's strategy, its organizational governance, results and perspectives in the context of

\footnotetext{
${ }^{13}$ R. Sroka, Raportowanie społeczne na świecie [in:] N. Ćwik (ed.), Wspólna odpowiedzialność..., p. 14.

${ }^{14}$ International Organization for Standardization, ISO 26000:10, Guidance on Social Responsibility, https://www.iso.org/obp/ui/\#iso:std:iso:26000:ed-1:v1:en (access: 10.02.2018).

${ }^{15} \mathrm{R}$. Sully, ISO 26000: the business guide to the new standard on social responsibility, „Impact Assessment and project Appraisal", 2012, Vol. 30, No. 3, p. 214.

16 T. Martyniuk, K. Szawczak, Raportowanie spotecznej odpowiedzialności przedsiębiorstw, Prace Naukowe Uniwersytetu Ekonomicznego we Wrocławiu „Przyszłość rachunkowości i sprawozdawczości - założenia, zasady, definicje. Ujawnienia informacji w sprawozdaniu finansowym”, 2013, nr 314, p. 111.

17 AccountAbility, Standards, http://www.accountability.org/standards/ (access: 12.02.2018).

18 OECD Guidelines for Multinational Enterprises 2011 Edition, 2011, https://www.oecd.org/ corporate/mne/48004323.pdf, p. 31-63 (access: 11.02.2018).
} 
the external environment impact values in the short, medium and long-term ${ }^{19}$. Undoubtedly this is the future of business reporting since it will be possible to include in one report both financial and social issues as well as the relationships between them.

The need for standardizing the reporting process of non-financial data has been noticed not only at the international level but also in Poland. In order to facilitate companies' adaptation to reporting requirements imposed by the Directive 2014/95/EU of the European Parliament and of the Council ${ }^{20}$ a national Non-Financial Information Standard (Standard Informacji Niefinansowych, SIN) was published in October of 2017. It was created through the initiative of the Polish Association of Listed Companies and the Foundation for Reporting Standards and its development was the result of the engagement of experts representing both business as well as the non-governmental sector ${ }^{21}$.

The standard consists of two crucial parts. The first contains basic rules of non-financial reporting as well as the suggested scope of disclosures in three areas (management, environmental and employee) along with examples of indicators which can be utilized to achieve it. Within the second part several annexes updating and explaining individual parts of the Standard have been prepared. An important issue is the fact that the goal of SIN is not to compete with other norms or guidelines of this type but the creation of regulations most suited to the Polish reality. The standard is mainly addressed to those enterprises which have never before prepared these types of reports and are only beginning their experience with non-financial reporting and for whom the utilization of the best-known international regulations of this type could be an insurmountable organizational challenge ${ }^{22}$.

The presented standards, norms and guidelines comprise only a portion of initiatives which, on the one hand, aim to propagate social reporting and, on the other, are a move toward their standardization. Since a universal standard for these types of reports has not so far been developed it becomes necessary to integrate various standards, norms and guidelines and, on their basis, create an individual framework of reporting adequate to address the characteristics of a given entity as well as its corporate social responsibility strategy ${ }^{23}$.

\section{PRACTICAL APPLICATION OF STANDARDS, NORMS AND GUIDELINES IN THE PROCESS OF REPORTING ON CORPORATE SOCIAL RESPONSIBILITY BY COMPANIES OF THE RESPECT INDEX}

The RESPECT Index initiated in 2009 is the first index in East-Central Europe associating socially responsible companies. Its structures are created by entities which

${ }^{19}$ IIRC, International Integrated Reporting Framework, http://integratedreporting.org/wp-content/ uploads/2015/03/13-12-08THEINTERNATIONAL-IR-FRAMEWORK-2-1.pdf, p. 8 (access: 10.02.2018).

${ }^{20}$ Directive 2014/95/EU of the European Parliament and of the Council of 22 October 2014 amending Directive 2013/34/EU as regards disclosure of non-financial and diversity information by certain large undertakings and groups (OJ L 330, 15.11.2014). Starting in 2018 it imposes additional reporting responsibilities on large public interest entities in regard to the presentation of environmental matters, social and employee-related matters, respect for human rights, anticorruption and bribery matters.

${ }^{21}$ Fundacja Standardów Raportowania, Standard Informacji Niefinansowych, 2017, https: //standardy.org.pl/wppsndrd/wp-content/uploads/2017/10/SIN.pdf, p. 9 (access: 07.02.2018).

22 Ibidem.

${ }^{23}$ E. Różańska, Integracja standardów raportowania..., p. 175-176. 
operate in compliance with the best management standards related to corporate and informational governance as well as within the ecological, social and employee related spheres ${ }^{24}$. This responsibility is expressed not only through the initiation of particular activities relating to CSR but also with meeting the informational needs of individual groups of stakeholders. This does not solely concern the disclosure of financial information but also those referring to economic, social and environmental aspects.

This can be seen in the fact that approximately $68 \%$ of the 28 companies making up the index prepare separate corporate social responsibility reports and results from their awareness that information provided in those reports is an important criterion for the assessment of the company's operations.

The content of presented information as well as its high quality and comparability becomes especially significant. For that reason, the utilization of particular standards, norms and guidelines supporting the process of non-financial reporting is crucial (table 1).

Table 1. References to standards, norms and guidelines of companies included in the RESPECT Index and preparing reports concerning corporate social responsibility

\begin{tabular}{|c|c|c|c|c|c|c|c|c|c|}
\hline \multirow[b]{2}{*}{ Company } & \multirow[b]{2}{*}{ Report name } & \multicolumn{7}{|c|}{ Standards, norms, and guidelines on non-financial reporting } & \multirow{2}{*}{$\begin{array}{c}\text { Inde- } \\
\text { pendent } \\
\text { external } \\
\text { verifica- } \\
\text { tion } \\
\end{array}$} \\
\hline & & GRI & $\begin{array}{c}\text { ISO } \\
26000\end{array}$ & UN GC & OECD & $\begin{array}{l}\text { AA } \\
\text { 1000 } \\
\text { SES }\end{array}$ & IIRC & SIN & \\
\hline $\begin{array}{l}\text { Orange } \\
\text { Polska }\end{array}$ & $\begin{array}{l}\text { Orange Polska } \\
\text { Integrated Report } \\
2016\end{array}$ & $\mid \begin{array}{c}\text { GRI G4 } \\
(\text { core })\end{array}$ & $\checkmark$ & $\checkmark$ & $\checkmark$ & - & $\checkmark$ & - & $\checkmark$ \\
\hline mBank & $\begin{array}{l}\text { Annual Report } \\
2016 \text { (integrated } \\
\text { report) }\end{array}$ & $\begin{array}{c}\text { GRI G4 } \\
(\text { core })\end{array}$ & $\checkmark$ & $\checkmark$ & - & - & $\checkmark$ & - & - \\
\hline Agora & $\begin{array}{l}\text { Agora Group } \\
2016 \text { Non-Finan- } \\
\text { cial Statement }\end{array}$ & $\begin{array}{c}\text { GRI G4 } \\
\text { (core) }\end{array}$ & $\checkmark$ & $\checkmark$ & - & - & - & $\checkmark$ & - \\
\hline $\begin{array}{l}\text { LW } \\
\text { Bogdanka }\end{array}$ & $\begin{array}{l}\text { Integrated Report } \\
\text { GK LW Bog- } \\
\text { danka for } 2016\end{array}$ & $\begin{array}{c}\text { GRI G4 } \\
(\text { core })\end{array}$ & $\checkmark$ & - & - & - & $\checkmark$ & - & - \\
\hline $\begin{array}{l}\text { Trakcja } \\
\text { PRKiI }\end{array}$ & \begin{tabular}{|l|} 
Integrated Report \\
2016
\end{tabular} & $\begin{array}{c}\text { GRI G4 } \\
\text { (core) }\end{array}$ & $\checkmark$ & - & - & - & $\checkmark$ & - & $\checkmark$ \\
\hline Budimex & $\begin{array}{l}\text { Integrated annual } \\
\text { Report for } 2016\end{array}$ & $\begin{array}{c}\text { GRI G4 } \\
\text { (core) }\end{array}$ & $\checkmark$ & $\checkmark$ & - & - & - & - & $\checkmark$ \\
\hline $\begin{array}{l}\text { Grupa } \\
\text { LOTOS }\end{array}$ & $\begin{array}{l}\text { Integrated annual } \\
\text { Report } 2016\end{array}$ & $\begin{array}{c}\text { GRI G4 } \\
(\text { core })\end{array}$ & - & $\checkmark$ & - & - & $\checkmark$ & - & - \\
\hline Tauron PE & $\begin{array}{l}\text { Integrated Report } \\
2016\end{array}$ & $\begin{array}{c}\text { GRI G4 } \\
\text { (core) }\end{array}$ & - & - & - & $\checkmark$ & $\checkmark$ & - & $\checkmark$ \\
\hline $\begin{array}{l}\text { Elektro- } \\
\text { budowa }\end{array}$ & \begin{tabular}{|l|} 
Corporate social \\
responsibility \\
Report 2016
\end{tabular} & $\begin{array}{c}\text { GRI G4 } \\
\text { (core) }\end{array}$ & - & $\checkmark$ & - & - & - & - & - \\
\hline PGE & $\begin{array}{l}\text { 2016 Integrated } \\
\text { Report }\end{array}$ & $\begin{array}{c}\text { GRI G4 } \\
\text { (core) }\end{array}$ & - & $\checkmark$ & - & - & - & - & - \\
\hline
\end{tabular}

${ }^{24}$ RESPECT Index, Opis projektu, http://www.odpowiedzialni.gpw.pl/opis_projektu (access: 11.02.2018). 
Table 1 (cont.). References to standards, norms and guidelines of companies included in the RESPECT Index and preparing reports concerning corporate social responsibility

\begin{tabular}{|c|c|c|c|c|c|c|c|c|c|}
\hline \multirow[b]{2}{*}{ Company } & \multirow[b]{2}{*}{ Report name } & \multicolumn{7}{|c|}{ Standards, norms, and guidelines on non-financial reporting } & \multirow{2}{*}{$\begin{array}{c}\text { Inde- } \\
\text { pendent } \\
\text { external } \\
\text { verifica- } \\
\text { tion } \\
\end{array}$} \\
\hline & & GRI & $\begin{array}{c}\text { ISO } \\
26000\end{array}$ & UN GC & OECD & $\begin{array}{l}\text { AA } \\
\text { 1000 } \\
\text { SES }\end{array}$ & IIRC & SIN & \\
\hline BZ WBK & $\begin{array}{l}\text { 2016 Corporate } \\
\text { Social Responsi- } \\
\text { bility Report }\end{array}$ & $\begin{array}{c}\text { GRI G4 } \\
(\text { core })\end{array}$ & - & - & - & $\checkmark$ & - & - & $\checkmark$ \\
\hline $\begin{array}{l}\text { ING Bank } \\
\text { Śląski }\end{array}$ & $\begin{array}{l}\text { Integrated Annual } \\
\text { Report of ING } \\
\text { Bank Śląski S.A. } \\
2016 \\
\end{array}$ & $\begin{array}{c}\text { GRI G4 } \\
\text { (core) }\end{array}$ & - & - & - & - & $\checkmark$ & - & - \\
\hline $\begin{array}{l}\text { KGHM } \\
\text { Polska } \\
\text { Miedź }\end{array}$ & $\begin{array}{l}\text { Integrated Report } \\
2016\end{array}$ & $\begin{array}{c}\text { GRI G4 } \\
(\text { core })\end{array}$ & - & - & - & - & $\checkmark$ & - & - \\
\hline $\begin{array}{l}\text { Bank } \\
\text { Millennium }\end{array}$ & $\begin{array}{l}2016 \text { Bank Mil- } \\
\text { lennium Financial } \\
\text { and Social Report }\end{array}$ & $\begin{array}{c}\text { Stand- } \\
\text { ards } \\
\text { GRI } \\
\text { (core) } \\
\end{array}$ & - & - & - & - & - & - & $\checkmark$ \\
\hline Apator & Report CSR 2016 & $\begin{array}{c}\text { GRI G4 } \\
\text { (core) }\end{array}$ & - & - & - & - & - & - & - \\
\hline PGNIG & \begin{tabular}{|l} 
PGNiG Group \\
CSR Report 2014
\end{tabular} & $\begin{array}{c}\text { GRI G4 } \\
\text { (core) }\end{array}$ & - & - & - & - & - & & $\checkmark$ \\
\hline Energa & $\begin{array}{l}\text { Our Responsibil- } \\
\text { ity 2016 (CSR } \\
\text { report) }\end{array}$ & $\begin{array}{c}\text { GRI G4 } \\
(\text { core })\end{array}$ & - & - & - & - & - & - & - \\
\hline $\begin{array}{l}\text { Grupa } \\
\text { Azoty }\end{array}$ & $\begin{array}{l}\text { Grupa Azoty } \\
\text { Integrated Report } \\
2015\end{array}$ & $\begin{array}{c}\text { GRI G4 } \\
(\text { core })\end{array}$ & - & - & - & - & - & - & $\checkmark$ \\
\hline PZU & $\begin{array}{l}\text { PZU SA'S } \\
\text { Corporate Social } \\
\text { Responsibility } \\
\text { Report for } \\
2015-2016\end{array}$ & $\begin{array}{c}\text { GRI G4 } \\
(\text { core })\end{array}$ & - & - & - & - & - & - & - \\
\hline
\end{tabular}

Source: Author's own work based on social and integrated reports prepared by companies included in the RESPECT Index.

Of greatest importance in the area of social reporting are regulations developed by the Global Reporting Initiative. This is proven by the fact that the reports of as many as 18 companies belonging to the RESPECT index comply with GRI G4 Guidelines. Additionally, in its reporting process the Bank Millennium S.A. already utilizes the newest standards of this kind (GRI Standards) which will definitively replace the G4 Guidelines on July of 2018. Equally important is the fact that all companies using both GRI G4 guidelines as well as GRI Standards achieve a core level of reporting which does not impose on the reporting enterprises the responsibility to disclose all indicators prescribed by regulations of this type.

The growing significance of the concept of integrated reporting also finds confirmation in interest shown to standards prepared by IIRC. References to this type of regulations can be found in as many as eight reports combining information concerning financial as well as 
non-financial aspects of enterprise's operation. Additionally, RESPECT Index companies willingly declare compliance of presented data with Global Compact principles and the ISO 26000 norm.

Another important issue is the fact that a large number of analyzed companies do not limit themselves to utilizing individual norms or guidelines but use an entire set of related tools. In the process of reporting, other than GRI G4 guidelines, RESPECT Index companies often reach for two (5 companies) or even three ( 2 companies) additional documents regulating non-financial reporting issues and the integrated report of Orange Polska S.A. simultaneously contains references to GRI G4 guidelines, the ISO 26000 norm, Global Compact principles, OECD guidelines as well as to standards prepared by the IIRC.

The conducted analysis additionally shows that some companies subject their reports to independent external verification conducted by auditing companies or GRI organizations. It is not, however, a standard procedure even among companies making up the RESPECT Index. This can cause certain doubts regarding the actual credibility of data presented in social reports and reduce the feeling of certainty that they can be a basis for correct decisionmaking of individual groups of stakeholder ${ }^{25}$. This determines further actions oriented at creating regulations obligating reporting enterprises to even greater authentication of presented non-financial information.

\section{CONCLUSIONS}

The growing importance of the concept of corporate social responsibility determines the need for establishing dialogue with a wide spectrum of stakeholders through publishing reports containing data dealing with the economic, social and environmental context of companies' operation. In order to meet market demands connected with ensuring reliability as well as comparability of reports prepared by individual entities, the utilization of standards, norms and guidelines supporting the process of non-financial reporting becomes crucial since they facilitate not only the creation of such reports but also, from the perspective of stakeholders, increase their usefulness.

The conducted analysis allowed us to positively verify the research hypothesis posed within this article. Companies included in the RESPECT Index eagerly utilize standards, norms and guidelines in their process of non-financial reporting. Especially significant are principles developed by GRI which are used by nearly all reporting entities. Substantial interest in their employment results from the fact that they comprehensively define what a properly prepared report should contain. They include general rules and tips making the reporting process easier as well as indicators through which enterprises can measure and communicate their impact on the environment. Important is the fact that regulations developed by GRI are not by nature static but are continually improved to make nonfinancial reporting more transparent and complete. This is further confirmed by the fact that although the newest GRI Standards will not replace the still binding GRI G4 guidelines until July of 2018 they are already being utilized in the process of non-financial reporting.

Although the framework for non-financial reporting developed by GRI is dominant in this field it is not the only set of regulations currently being used. Growing significance is assigned to standards developed by IIRC. Some RESPECT Index companies, seeing the

${ }^{25}$ Global Reporting Initiative, The external assurance of sustainability reporting, 2013, https: //www.globalreporting.org/resourcelibrary/GRI-Assurance.pdf, p. 5 (access: 07.02.2018). 
growing importance of non-financial reporting in building relationships with the stakeholders, forgo typical social reports and prepare integrated reports allowing them to combine financial information with information concerning corporate social responsibility.

Reports prepared by companies included in the RESPECT index concerning the issue of social responsibility are an important management tool compelling them to extensively analyze their responsibility and business processes. On the other hand, they are also an important tool for establishing dialogue between the enterprise and its environment. This is the reason that efforts to standardize provided data in order to ensure adequate quality of these reports, improve their reliability and assure their greater comparability, are important. Standardization of these reports will undoubtedly also contribute to enact changes in CSR related activity from being centered on maintaining companies' images into actions making up their strategy. This alteration of direction is significant when it is considered that nonfinancial reporting is, for some of these enterprises, becoming a legal obligation rather than a voluntary element of their disclosures. One example are the regulations of the Directive 2014/95/EU of the European Parliament and of the Council from 2014 whose interpretations have found their way into the Polish Non-Financial Information Standard (SIN).

\section{REFERENCES}

1. Anam L., Zasady raportowania - podstawa prawidtowego sporządzania raportów [in:] N. Ćwik (ed.), Wspólna odpowiedzialność. Rola raportowania społecznego, Forum Odpowiedzialnego Biznesu, Warszawa, 2013.

2. Dyląg R., Puchalska E., Raportowanie zagadnień środowiskowych i społecznych, „Zeszyty Teoretyczne Rachunkowości”, t. 75 (131), SKwP, Warszawa 2014.

3. Kacprzak J., Anam L., Raportowanie niefinansowe. Poradnik dla raportujacych firm, Warszawa 2017.

4. Lemus E., The importance of CSR in Financial Reporting Standards, „Global Journal of Management and Business Research: D Accounting and Auditing”, 2016, Vol. 16, Issue 2.

5. Martyniuk T., Szawczak K., Raportowanie społecznej odpowiedzialności przedsiębiorstw, Prace Naukowe Uniwersytetu Ekonomicznego we Wrocławiu „Przyszłość rachunkowości i sprawozdawczości - założenia, zasady, definicje. Ujawnienia informacji w sprawozdaniu finansowym", 2013, nr 314, s. 111.

6. Mazurowska M., Analiza porównawcza wytycznych Global Reporting Initative oraz International Integrated Reporting Comitee, „Studia Oeconomica Posnaniensia” 2015, Vol. 3, No. 1.

7. Pakowska S., Wytyczne G3 I G3.1 Global Reporting Initiative dotyczace raportowania kwestii zrównoważonego rozwoju - analiza porównawcza, ,Zarządzanie i Finanse” 2012, nr 1 (2).

8. Paszkiewicz A., Szadziewska A., Raportowanie rozwoju zrównoważonego przedsiębiorstw wedtug wytycznych GRI, Zeszyty Naukowe Uniwersytetu Szczecińskiego nr 668 „Finanse, Rynki Finansowe, Ubezpieczenia”, 2011, nr 41.

9. Różańska E., Integracja standardów raportowania społecznej odpowiedzialności przedsiębiorstw, „Studia Oeconomica Posnaniensia”, 2015, Vol. 3, No. 1.

10. Samelak J., Zintegrowane sprawozdanie przedsiębiorstwa społecznie odpowiedzialnego, Wydawnictwo Uniwersytetu Ekonomicznego w Poznaniu, Poznań 2013. 
11. Sroka R., Raportowanie spoteczne na świecie [in:] N. Ćwik (ed.), Wspólna odpowiedzialność. Rola raportowania spotecznego, Forum Odpowiedzialnego Biznesu, Warszawa 2013.

12. Sully R., ISO 26000: the business guide to the new standard on social responsibility, „Impact Assessment and project Appraisal”, 2012, Vol. 30, No. 3.

\section{LEGAL ACT}

1. Directive 2014/95/EU of the European Parliament and of the Council of 22 October 2014 amending Directive 2013/34/EU as regards disclosure of non-financial and diversity information by certain large undertakings and groups (OJ L 330, 15.11.2014).

\section{INTERNET SOURCES}

1. AccountAbility, Standards, http://www.accountability.org/standards/ (access: 12.02.2018).

2. Fundacja Standardów Raportowania, Standard Informacji Niefinansowych, 2017, https://standardy.org.pl/wppsndrd/wp-content/uploads/2017/10/SIN.pdf (access: 07.02. 2018).

3. G4 Guidelines Transition to Standards, https://www.globalreporting.org/information/g4/ transition-to-standards/Pages/default.aspx (access: 11.02.2018).

4. Global Reporting Initiative, The external assurance of sustainability reporting, 2013, https://www.globalreporting.org/resourcelibrary/GRI-Assurance.pdf (access: 07.02.2018).

5. IIRC, International Integrated Reporting Framework, http://integratedreporting.org/wpcontent/uploads/2015/03/13-12-08THEINTERNATIONAL-IR-FRAMEWORK-2-1.pdf (access: 10.02.2018).

6. International Organization for Standardization, ISO 26000:10, Guidance on Social Responsibility, https://www.iso.org/obp/ui/\#iso:std:iso:26000:ed-1:v1:en (access: 10.02.2018).

7. Investment and Enterprise Responsibility Review: Analysis of investor and enterprise policies on corporate social responsibility, United Nations Conference on Trade and Development, New York and Geneva, 2011, http://www.unctad.org/en/docs/diaeed20101_en.pdf (access: 11.02.2018).

8. OECD Guidelines for Multinational Enterprises 2011 Edition, 2011, https://www.oecd. org/corporate/mne/48004323.pdf (access: 11.02.2018).

9. RESPECT Index, Opis projektu, http://www.odpowiedzialni.gpw.pl/opis_projektu (access: 11.02.2018).

10. United Nations Global Compact, After the signature. A Guide to engagement in the United Nations Global Compact, 2012, https://www.unglobalcompact.org/docs/news_events/8.1/ after_the_signature.pdf (access: 10.02.2018).

\section{STANDARYZACJA RAPORTOWANIA SPOŁECZNEJ ODPOWIEDZIALNOŚCI BIZNESU}

Celem artykułu jest przedstawienie standardów, norm, a także wytycznych, opracowywanych na rzecz standaryzacji raportowania społecznego ukierunkowanego na komunikowanie ekonomicznych, społecznych oraz środowiskowych skutków podejmowanych przez przedsiębiorstwa działań rynkowych. Artykuł koncentruje się również na prezentacji badań empirycz- 
nych ukazujących ich praktyczną implementację w obszarze raportowania społecznej odpowiedzialności biznesu przez spółki wchodzące w skład indeksu RESPECT. Biorąc pod uwagę tak sformułowany cel, w artykule przyjęto następującą hipotezę badawczą: spótki indeksu RESPECT dostrzegaja potrzebę zapewnienia wiarygodności oraz porównywalności ujawnianych danych niefinansowych, poprzez wykorzystanie najbardziej rozpowszechnionych standardów, norm $i$ wytycznych w obszarze raportowania spotecznej odpowiedzialności biznesu. Realizacja celu artykułu oraz weryfikacja hipotezy badawczej została dokonana w oparciu o przegląd literatury i dokumentów zawierających rekomendacje dotyczące raportowania społecznej odpowiedzialności biznesu, a także analizę treści raportów niefinansowych sporządzanych przez badane przedsiębiorstwa. Wyniki przeprowadzonych badań pozwoliły na przyjęcie stwierdzenia, że regulacje w zakresie raportowania społecznej odpowiedzialności biznesu zajmują istotne miejsce w raportach przygotowywanych przez spółki wchodzące w skład indeksu RESPECT. Szczególne znaczenie w tym obszarze mają wytyczne i standardy opracowywane przez Global Reporting Initiative. Niezbędne jest jednak podejmowanie dalszych działań na rzecz zapewnienia odpowiedniej jakości publikowanych raportów oraz zwiększenia ich zewnętrznej weryfikacji, dającej poczucie pewności, że raportowane dane są wiarygodne i mogą być podstawą podejmowania decyzji przez interesariuszy.

Słowa kluczowe: raportowanie społecznej odpowiedzialności, standaryzacja, spółki indeksu RESPECT.

DOI: $10.7862 /$ rz.2018.mmr.51

Tekst złożono do redakcji: lipiec $2018 r$. Tekst przyjęto do druku: grudzień 2018 r. 